\title{
Comparative transcriptome analysis of stylar canal cells identifies novel candidate genes implicated in the self-incompatibility response of Citrus clementina
}

Marco Caruso', Paz Merelo², Gaetano Distefano', Stefano La Malfa', Angela Roberta Lo Piero ${ }^{1}$, Francisco R Tadeo ${ }^{2}$, Manuel Talon ${ }^{2}$ and Alessandra Gentile 1* $^{*}$

\begin{abstract}
Background: Reproductive biology in citrus is still poorly understood. Although in recent years several efforts have been made to study pollen-pistil interaction and self-incompatibility, little information is available about the molecular mechanisms regulating these processes. Here we report the identification of candidate genes involved in pollen-pistil interaction and self-incompatibility in clementine (Citrus clementina Hort. ex Tan.). These genes have been identified comparing the transcriptomes of laser-microdissected stylar canal cells (SCC) isolated from two genotypes differing for self-incompatibility response ('Comune', a self-incompatible cultivar and 'Monreal', a selfcompatible mutation of 'Comune').

Results: The transcriptome profiling of SCC indicated that the differential regulation of few specific, mostly uncharacterized transcripts is associated with the breakdown of self-incompatibility in 'Monreal'. Among them, a novel F-box gene showed a drastic up-regulation both in laser microdissected stylar canal cells and in selfpollinated whole styles with stigmas of 'Comune' in concomitance with the arrest of pollen tube growth. Moreover, we identify a non-characterized gene family as closely associated to the self-incompatibility genetic program activated in 'Comune'. Three different aspartic-acid rich (Asp-rich) protein genes, located in tandem in the clementine genome, were over-represented in the transcriptome of 'Comune'. These genes are tightly linked to a DELLA gene, previously found to be up-regulated in the self-incompatible genotype during pollen-pistil interaction.

Conclusion: The highly specific transcriptome survey of the stylar canal cells identified novel genes which have not been previously associated with self-pollen rejection in citrus and in other plant species. Bioinformatic and transcriptional analyses suggested that the mutation leading to self-compatibility in 'Monreal' affected the expression of non-homologous genes located in a restricted genome region. Also, we hypothesize that the Asprich protein genes may act as $\mathrm{Ca}^{2+}$ "entrapping" proteins, potentially regulating $\mathrm{Ca}^{2+}$ homeostasis during self-pollen recognition.
\end{abstract}

\section{Background}

Among the citrus species, several pummelos (Citrus grandis L. Osbeck) and mandarin-like varieties are selfincompatible [1]. Clementine mandarin (Citrus clementina Hort. ex Tan.), derived from an uncontrolled cross between a sweet orange and a mandarin, is probably the

\footnotetext{
* Correspondence: gentilea@unict.it

'Dipartimento di Scienze delle Produzioni Agrarie e Alimentari, Università degli Studi di Catania, Via Valdisavoia 5, 95123 Catania, Italy

Full list of author information is available at the end of the article
}

most widespread citrus species showing self-incompatibility (SI). It is characterized by gametophytic SI, with the pollen tubes stopping their growth in the upper or middle style [2,3]. Moreover, in this species SI is coupled with a variable degree of parthenocarpy. SI and parthenocarpy in citrus are very important traits for fruit production because they result in seedless fruits, which have a higher value in the markets compared to the seeded ones. Therefore, understanding the molecular
() Biomed Central

(c) 2012 Caruso et al; licensee BioMed Central Ltd. This is an Open Access article distributed under the terms of the Creative Commons Attribution License (http://creativecommons.org/licenses/by/2.0), which permits unrestricted use, distribution, and reproduction in any medium, provided the original work is properly cited. 
basis of SI would be important to plan marker-assisted breeding to obtain new seedless genotypes.

Despite the importance of this trait, the genetic basis are still poorly understood and the key genes of SI have not been identified yet. The study of populations segregating for SI might be definitely a powerful strategy to give new insights into its genetic basis. However, the difficulties to obtain and characterize appropriate populations, with a variable degree of parthenocarpy and female/male sterility observed in the progeny might limit this approach. Such kind of strategy for the identification of the S-locus was carried out analyzing several crosses among different citrus cultivar and accessions with Got-3 isozyme, which is thought to be linked with the S-locus [4], providing only a rough estimation of their possible S-genotype.

In recent times, different research groups attempted to better understand SI and pollen-pistil interaction in several citrus genotypes, mainly trying to characterize putative homologs of key genes and proteins of already characterized SI systems. Gentile and colleagues [5] reported the involvement of $\mathrm{Ca}^{2+}$-dependent transglutaminase (TGase) in the self-incompatible response in pummelo, as already reported for Rosaceae [6]. Regarding the S-locus genes, a S-like RNase has been isolated from 'Zigui shatian' pummelo [7], however the authors suggested that this gene might play an important role during ovary senescence rather than in the incompatibility response. Another S-like RNase has been isolated from a mandarin variety and was partially characterized [8], but it's not still clear whether this gene is the key determinant for the self-incompatible response.

To overcome these limits, the transcriptome analysis of natural mutants displaying contrasting compatibility behaviour might be more effective to better understanding the molecular basis controlling the progamic phase in citrus. Over the last decade, the genome and/or transcriptome analysis of natural or induced citrus mutants have been a powerful strategy to study the molecular basis of agronomically important traits, such as ripening period, fruit pigmentation, seedlessness and other traits related to quality [9-12]. Concerning SI, a few citrus natural mutants displaying different sexual behaviour with respect to their original varieties have been identified and characterized [13-16]. Differences between the mutants and the original cultivars were related to differences in pollen [13], style [15] or ovary [14] functionality. In some cases, different behaviours during the progamic phase were associated to abnormal embryo development $[13,16]$. Therefore, it seems clear the mechanisms preventing fertilization are different in these genotypes, so it's reasonable to hypothesize that the mutations affected different genes or pathways implicated in reproduction.
Recently we chose two clementine clones with contrasting behaviour relating to self-pollen recognition ('Comune', self-incompatible; and 'Monreal', self-compatible mutation of 'Comune' [17]) as a model to identify candidate genes implicated in pollen-pistil interaction. Histological assays and analysis of pollen tube kinetics were performed to study the pollen tube behaviour in the two genotypes, and to assess whether the breakdown of SI in 'Monreal' was caused by changes in pistil or pollen functionality. The analysis demonstrated that the 'Monreal' mutation affected pistil functions, since pollen tubes of the two varieties grew equally in the pistils of self-compatible mutant, while 'Comune' rejected the pollen of both varieties, recognizing the pollen of 'Monreal' as self-pollen [15]. A first transcriptome comparison was conducted analyzing whole styles with stigmas, leading to the identification of a first set of genes differentially expressed in non-pollinated flowers and during pollentube elongation in self-pollination condition [15] including stress related genes, and transcripts related to $\mathrm{Ca}^{2+}$ and hormone signalling. Surprisingly, a relatively high number of gene tags of different classes of retrotransposons were isolated, indicating their possible activation in response to pollination. However, the cDNA-AFLP analysis covered only part of the transcriptome and, due to the presence of pollen tubes growing along the pistil, the isolated gene tags were presumably not pistil-specific.

Here we describe a complementary approach to identify another set of candidate genes in 'Comune' and 'Monreal', to provide a better view of the molecular aspects related to citrus reproduction. We used laser capture microdissection (LCM), which has been efficiently used to investigate several aspects of plant reproductive biology [18-21]. In our approach, LCM was coupled to microarray analysis to identify genes specifically expressed in the stylar canal cells (SCC). We demonstrate that our transcriptomic survey of SCC is an efficient strategy to discover candidate genes involved in the SI response in clementine.

\section{Results}

\section{Laser microdissection of SCC and microarray analysis}

Clementine pistil is composed of 10 or 11 fused carpels, which are assembled around an inner channel, and all sharing a common wet stigma that bears unicellular and multicellular papillae. Stylar canals are layered radially and lead to the ovary locules. Each canal is bordered by rectangular papillar cells, described in lemon [22] and 'Nova' mandarin [23]. SCC are placed with their long axis orthogonal to the canal. Although in some cases it is possible to see few pollen tubes growing within the inner channel [23] the majority of pollen tubes grows inside the stylar canals. As a result, these cells play a pivotal role in pollen-pistil interaction. To isolate the 
SCC, $10 \mu \mathrm{m}$ transversal sections were cut from OCT (optimal cutting temperature)-embedded styles with stigmas in the upper third of the style before pollen tubes arrive. Once we checked the integrity of the embedded tissues, we performed the LCM of the SCC (Figure 1), discarding other tissues such as parenchyma and vascular bundles. Also, sections from the stigma were discarded, since stigma is not the site where SI reaction occurs [15]. Around 10,000 cells were microdissected from each biological replicate. The isolated RNA was not sufficient for the microarray hybridizations, therefore a two-round RNA amplification was performed. Additional file 1 shows the Agilent Bioanalyzer profiles of the biotin-labeled amplified RNA (aRNA) after the second round of amplification. aRNAs ranged from 200 to $2000 \mathrm{bp}$, with a peak around $600 \mathrm{bp}$, indicating the good quality of the aRNA after the in vitro transcription protocol.

Biotin-labeled aRNA was hybridized on the Affymetrix Citrus GeneChip ${ }^{\circledR}$ which contains 30,171 probe sets representing up to 33,879 citrus transcripts from several citrus species and hybrids. The array is estimated to represent about 15,500 genes [24].

The three biological replicates of 'Comune' and 'Monreal' were compared using the Rank Products (RP) method. RP is a non-parametric analysis method which has been proven to be particularly sensitive in case of small number of biological replicates and large betweenstudy variation [25]. The last aspect is of outstanding importance in our experiment, because sample processing might increase variability among replicates [26]. RP analysis detects genes that are consistently found among the most strongly up-regulated or down-regulated genes in a number of replicate experiments [27]. In our experiment, the comparison of transcriptomes of highly specific cells at the same physiological conditions resulted in a low number of differentially expressed genes identified between the self-incompatible and the self-compatible genotypes (Table 1). Specifically, 10 genes were overrepresented in the SCC of the self-incompatible 'Comune', while 7 were over-represented in 'Monreal'. In general the differentially expressed genes showed a significant fold change-difference, especially in the case of the transcripts preferentially expressed in 'Comune'. They did not reveal any functional enrichment and were not homologous to genes previously characterized as involved in pollen-pistil interaction. Actually, many of the candidate genes were not previously annotated in other plant species.

For Real time quantitative RT-PCR (qRT-PCR) validations of the microarray results (Figure 2), total RNA was isolated from separate bulks of SCC, from which tworound unlabeled aRNA was synthesized. All the 'Comune' up-regulated genes were validated by qRT-PCR. Regarding the 'Monreal' over-represented genes, only one was not validated (cit.8702, corresponding to an extensin, data not shown), while cit.7192 was discarded for the presence of unspecific PCR products.

\section{An F-box is the most up-regulated gene in the SCC of the self-incompatible genotype}

cit.7568 was the unigene which showed the highest foldchange value, with more than 37 -fold over-representation in 'Comune' (Table 1). This unigene is represented in the GeneChip by a single clone of a $C$. sinensis callus library. Attempts to get a deduced amino acid sequence of the cit.7568 unigene led to no reliable predictions. Actually, partial cDNA amplification and sequencing of cit.7568 revealed that the transcript expressed in the SCC of 'Comune' was 209 bp longer, sharing higher similarity to a single EST from C. sinensis early-developing fruits [GenBank: EY696233]. Sequencing of the genomic region surrounding the Open Reading Frame (ORF) revealed allelic variation, and translation evidenced a non-functional

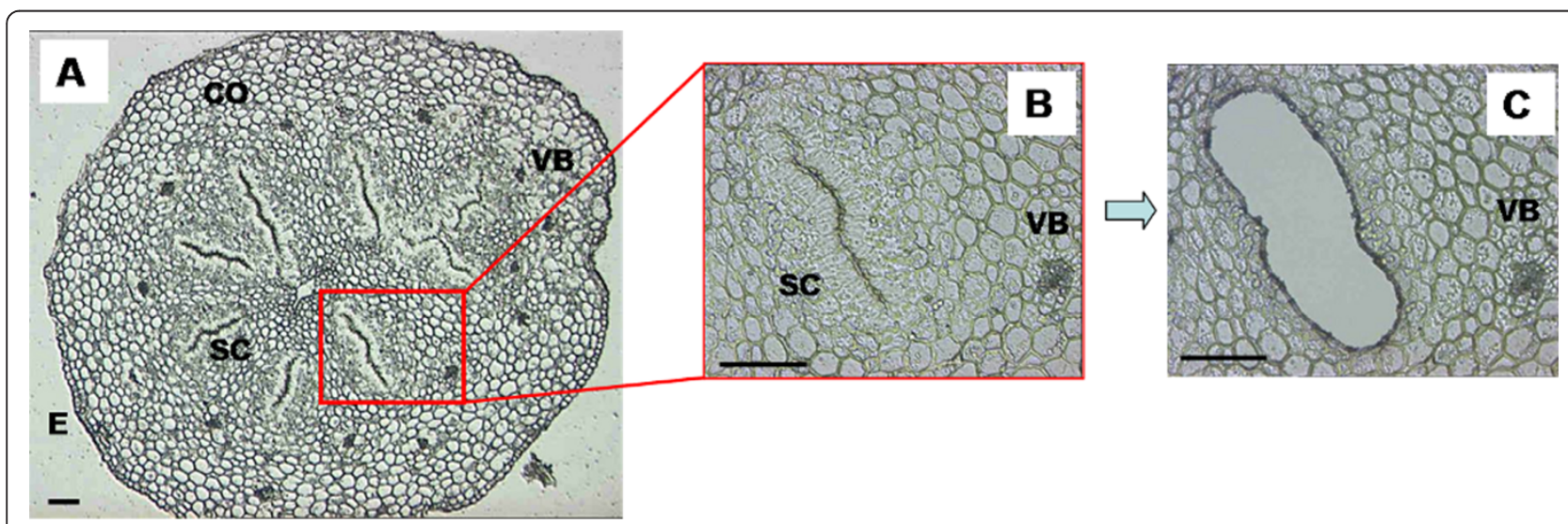

Figure 1 Isolation of stylar canal cells using Laser capture microdissection (LCM). $10 \mu \mathrm{m}$-thick transversal section of 'Comune' clementine style (A), before (B) and after (C) laser microdissection. CO: cortex; E: epidermis; SC: stylar canals; VB: vascular bundles. Scale bar $100 \mu \mathrm{m}$. 
Table 1 List of genes showing differential expression between 'Comune' (self-incompatible) and 'Monreal' (selfcompatible) stylar canal cells

\begin{tabular}{|c|c|c|c|c|}
\hline Probe set & Putative function & $\begin{array}{l}\text { Fold } \\
\text { change }\end{array}$ & PFP & $\begin{array}{c}P \\
\text { value }\end{array}$ \\
\hline \multicolumn{5}{|c|}{$\begin{array}{l}\text { Over-represented in the self incompatible } \\
\text { (Comune) }\end{array}$} \\
\hline Cit.7568.1.S1_at & putative F-box & 37.14 & 0 & 0 \\
\hline Cit.11563.1.S1_at & No homology with functionally annotated proteins & 16.15 & 0 & 0 \\
\hline Cit.5456.1.S1_at & No homology with functionally annotated proteins & 4.72 & 0.06 & 0 \\
\hline Cit.5776.1.S1_s_at & No homology with functionally annotated proteins & 11.99 & 0.002 & 0 \\
\hline Cit.7855.1.S1_at & No homology with functionally annotated proteins & 14.02 & 0 & 0 \\
\hline Cit.4399.1.S1_s_at & Oligopeptide transporter-ISP4-like protein & 17.05 & 0 & 0 \\
\hline Cit.24884.1.S1_at & Thioredoxin (TRX)-like [2Fe-2S] Ferredoxin (Fd) family & 4.98 & 0.04 & 0 \\
\hline Cit.7174.1.S1_at & Aspartyl protease & 5.39 & 0.03 & 0 \\
\hline Cit.19302.1.S1_at & Chalcone synthase & 5.4 & 0.04 & 0 \\
\hline Cit.18732.1.S1_s_at & PSBS; photosystem II $22 \mathrm{kDa}$ protein & 5.71 & 0.06 & 0 \\
\hline \multicolumn{5}{|c|}{$\begin{array}{l}\text { Over-represented in the self compatible } \\
\text { (Monreal) }\end{array}$} \\
\hline Cit.12037.1.S1_at & No homology with functionally annotated proteins & 5.74 & 0.01 & 0 \\
\hline Cit.18491.1.S1_at & 40S Ribosomal protein S24 & 3.94 & 0.02 & 0 \\
\hline Cit.7192.1.S1_at & Glycosyltransferase, CAZy family & 4.34 & 0.03 & 0 \\
\hline Cit.1968.1.S1_s_at & Terpene synthase & 4.71 & 0.04 & 0 \\
\hline Cit.9890.1.S1_s_at & GASA gibberellin regulated cysteine-rich protein & 4.8 & 0.02 & 0 \\
\hline Cit.29299.1.S1_at & $\begin{array}{l}\text { similar to uncharacterized Arabidopsis mitochondrial gene } \\
\text { ATMG00030 }\end{array}$ & 4.35 & 0.04 & 0 \\
\hline Cit.8702.1.S1_s_at & Extensin & 3.85 & 0.05 & 0 \\
\hline
\end{tabular}

PFP, percentage of false-positives

allele, having 100\% homology with the cit.7568 locus of the clementine haploid genome, and a functional allele, which encodes an intronless 268 amino acids F-box protein [GenBank: JN885720]. A $1.5 \mathrm{~kb}$ region spanning the putative F-box locus was sequenced but no polymorphisms were detected between 'Comune' and 'Monreal', indicating that the differential transcriptional regulation was not related to nucleotide polymorphisms. BlastX search showed that the predicted functional ORF shared homology to a poplar putative F-box protein [Uniprot: B9H9G5]. The putative Arabidospis ortholog (At5g04010) was annotated as a non-specific F-box. Interproscan identified a single F-box domain Skp2-like (IPR022364) and no additional protein motif structures. The F-box domain was similar to the one of SLEEPY (SLY1) F-box of Arabidopsis (At4g24210), that interacts with DELLA proteins and is involved in GA signalling [28]. However, no evident homology with SLY1 was observed outside the F-box domain.

Three aspartic acid-rich (Asp-rich) protein encoding genes are preferentially expressed in self-incompatible condition

Bioinformatic analyses added remarkable information regarding three unigenes found over-represented in 'Comune' (cit.11563, cit.5456 and cit.5776) and showing no functional annotation in available databases. The isolated genes represent three complete ORFs encoding small proteins containing 79, 53 and 74 amino acids, respectively. The deduced protein sequences share high homology degree and are characterized by an extremely high percentage of aspartic acid residues ranging from $19 \%$ (cit.5456) to $27 \%$ (cit.11563 and cit.5776) providing very low values of pI (3.64, 3.54 and 3.66, respectively). The alignment of the deduced amino acid sequences with other homologous proteins isolated from different plant sources shows that no significantly conserved sequences are detected in the first half of the $\mathrm{N}$-terminal region, whereas two highly conserved motifs are detected both in the second half of the $\mathrm{N}$-terminus and in the $\mathrm{C}$ terminus of the proteins. The first conserved motif is a poly-aspartate assembly usually spaced out by glycine residues followed by a second YDYAPAA motif, both of them being still uncharacterized. The aforesaid motifs can be repeated in tandem along the protein sequence as observed in cit.5776 that exhibits three poly-D/G + YDYAPAA motifs along the sequence (Figure 3). Interproscan search did identify neither known functional domains nor signal peptides. Moreover, secondary structure prediction studies carried out upon the three deduced protein sequences revealed that, except small $\mathrm{N}$-terminus regions likely folded as $\beta$-sheet, they are 


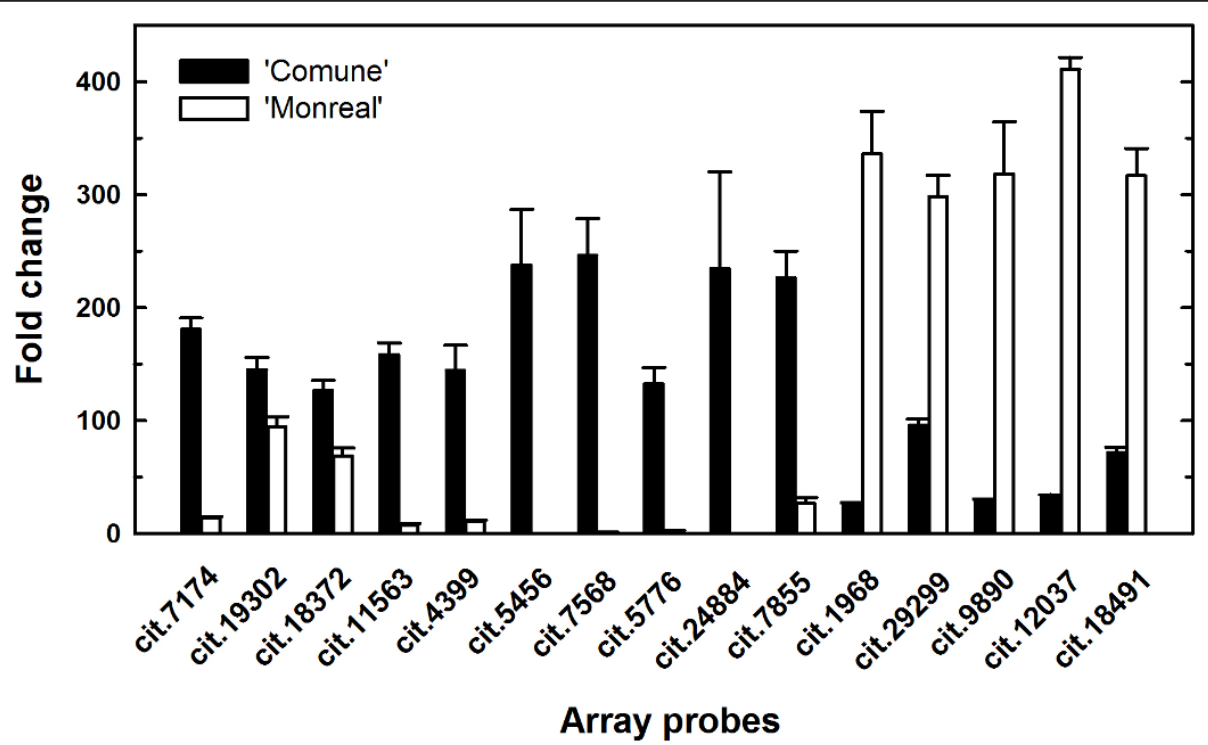

Figure 2 Validation of the differentially expressed genes. Relative expression levels of 15 unigenes in 'Comune' and 'Monreal' stylar canal cells determined using qRT-PCR, validating the microarray results. All genes are listed by their probe set ID of the Affymetrix Citrus GeneChip. Error bars indicate standard deviations from the mean.

randomly coiled leaving the aspartate residues exposed in the surrounding environment (data not shown).

Another interesting characteristic was identified analyzing the location of the Asp-rich protein genes in the recently released draft of the clementine (v0.9) and orange (v.1) genomes (Haploid Clementine Genome, International Citrus Genome Consortium, 2011, http:// www.phytozome.net/clementine; Sweet Orange Genome

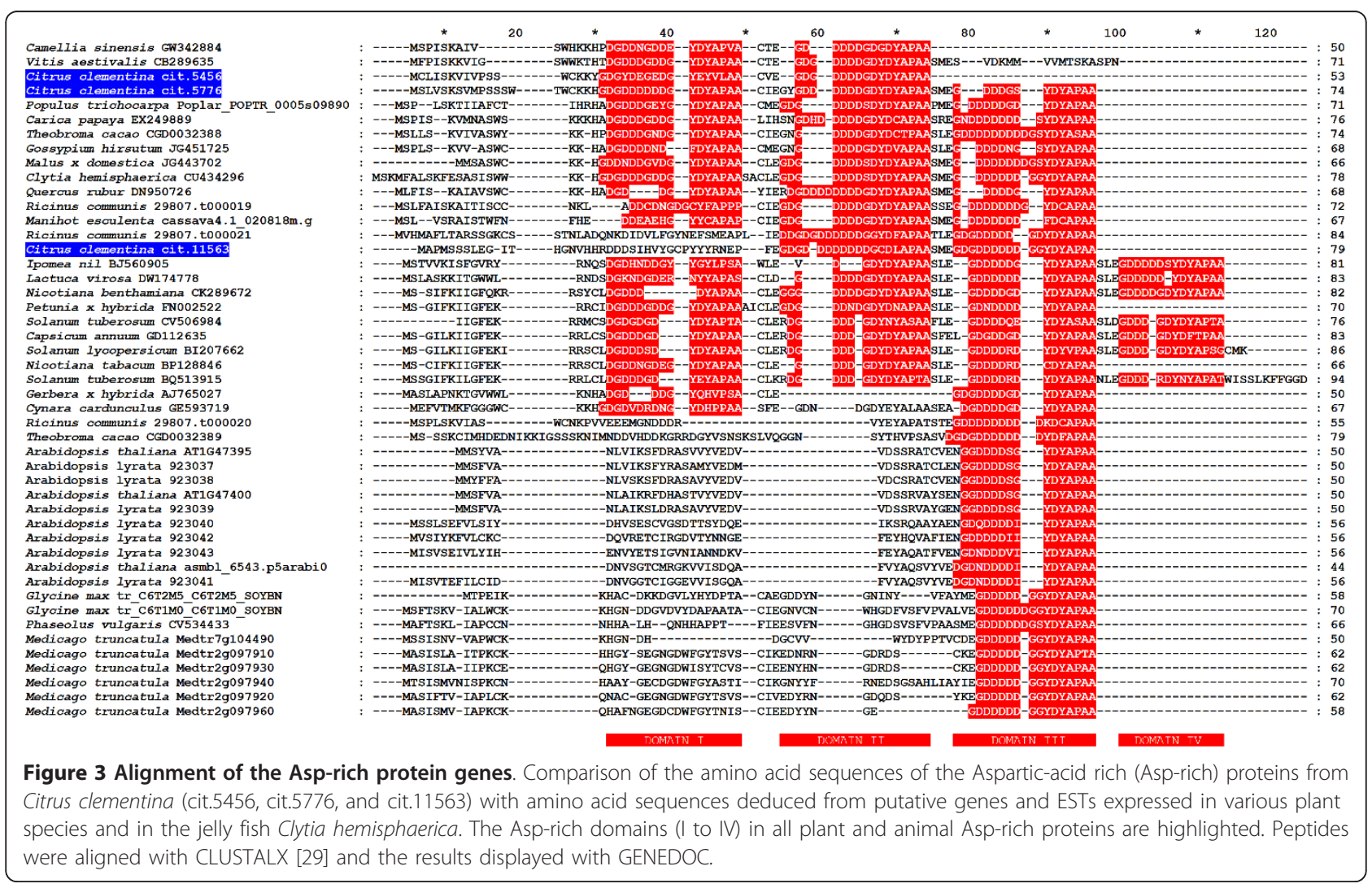


Project 2010, http://www.phytozome.net/citrus). That is, the 3 Asp-rich protein genes are located in tandem in a region of about $11 \mathrm{~kb}$. Specifically, the Asp-rich protein genes are positioned in scaffold 9 of the clementine genome (Table 2), and in scaffold 5 of the sweet orange genome. In both genomes this region is highly conserved, with minor differences located in the uncoding regions. The main one is represented by a deletion of $616 \mathrm{bp}$ in clementine, confirmed by PCR amplification and sequencing, in the region between cit.11563 and cit.5456 (data not shown). The Asp-rich protein genes are supported by a relatively low number of ESTs, for the most part found in non-flower-specific tissues subjected to stresses (Table 2).

Carrying out similarity searches among the sequenced plant genomes we identified Asp-rich homologs in Arabidopsis thaliana, Arabidopsis lyrata, Populus trichocarpa, Medicago truncatula, Glycine max, Ricinus communis, Theobroma cacao and Manihot esculenta. As in citrus, the Asp-rich protein genes are usually in tandem, with the number of linked genes depending on each species and varying from 2 to 7 . Exceptions are represented by poplar and cassava, where single copies are present. Moreover, soybean contains two putative Asp-rich proteins which are placed in different chromosomes, while in Medicago, in addition to 5 clustered Asp-rich located in chromosome 2, there are two unclustered identical Asp-rich in chromosome 7 (Medtr7g104220 and Medtr7g104490) which are elements of a duplicated region. $M$. truncatula and A. lyrata possess the highest number of Asp-rich paralogs (seven and six respectively), while A. thaliana displays three clustered Asp-rich proteins; two are predicted in the TAIR genome browser, release 9 (At1g47395 and At1g47400), while the third one has no Gene ID but was predicted using Fgenesh and is supported by 37 ESTs. In some cases, as in $A$. thaliana, gene predictions are supported by ESTs, while in others, such as Ricinus and Medicago, there are no EST corresponding to the prediction. The low EST support found in this species is probably due to the relatively low number of ESTs deposited in the databases, but also imply the highly specific role of this genes in specific metabolic processes.

Another search was performed against Uniprot and dbEST databases to identify other Asp-rich homologs and gene tags from additional species (Table 2). In the Asp-rich homologs, aspartate is still the prevalent residue, with an average percentage of $22 \%$ in the amino acids composition of the predicted proteins. Also, as the citrus Asp-rich proteins they are characterized by a short length (between 44 and 94 residues), by a variable number of poly-D/G domains (from one to four), and the majority presents the polyD/G + YDYAPAA at the C-terminus (Figure 3). As in the case of citrus, most of the identified ESTs were generated from stressed tissues, and in some cases from flowers, pointing out to a possible conserved role in different species. Interestingly, one EST belongs to a cDNA library from the jelly fish Clytia hemisphaerica suggesting that the role of this genes might not be plant-specific.

The phylogenetic analysis was conducted aligning the whole predicted protein sequences using ClustalX (Figure 3). The neighbor joining (NJ) tree separated the Asp-rich proteins into seven major groups, which are tentatively called subfamilies from A to G (Figure 4). Proteins with equal number of poly-D domains or similar domain organization usually grouped together. The $\mathrm{A}$ and $\mathrm{B}$ subfamily are divided into subclades comprising Asp-rich proteins which possess two or three conserved domains scattered along their sequence and a high percentage of Asp residues (from 19\% to 32\%). The $\mathrm{C}$ family consists of Asp-rich proteins from Solanaceae, plus a subcluster including Lactuca and Ipomoea proteins. Most of the proteins of the $C$ group possess 4 Asp-rich domains. D and $\mathrm{E}$ are small subfamilies which comprise, respectively, Asp-rich proteins from Gerbera $x$ hybrida and Cynara cardunculus (D), and from castor bean and cacao (E). Arabidospis proteins, containing a single poly-D domain at the $\mathrm{C}$-terminal region, are all grouped in the subfamily $\mathrm{F}$, while the Asp-rich proteins from legumes clustered in the subfamily G. The predicted sequences belonging to the groups $\mathrm{F}$ and $\mathrm{G}$ have a relatively low percentage of Asp (from 10\% to 20\%). The paralogs of M. truncatula and of the two Arabidopsis species display a high level of similarity and are tightly grouped. On the contrary, higher variability in length and number of the Asp-rich domains was observed in citrus, cacao and castor bean. It is noteworthy that the paralogs of these species belong to different sub-clades, suggesting a possible sub-functionalization.

\section{The genomic region surrounding the Asp-rich protein genes is conserved among genomes}

Further structural analysis of the genomic regions surrounding the Asp-rich protein genes evidenced another remarkable feature. Specifically, we identified a DELLA protein gene about $40 \mathrm{~kb}$ downstream the Asp-rich protein genes. DELLA was found to be differentially expressed in a previous transcriptome profiling [15]. In particular, its mRNA levels were higher in 'Comune' pollinated styles with stigmas compared to 'Monreal' ones.

The region between the Asp-rich protein genes and DELLA is highly conserved in C. clementina and C. sinensis genomes. Moreover, this segment showed collinearity with the genomes of two unrelated plants such as cacao (T. cacao) and castor bean (R. communis) (Figure 5). In the four genomes, the Asp-rich protein genes are in the same orientation of DELLA. Between the Asp-rich protein 
Table 2 Putative aspartic acid-rich (Asp-rich) protein genes found in different species, with information on the number of associated ESTs supporting their expression in different tissues, and total number of ESTs for each species

\begin{tabular}{|c|c|c|c|c|c|c|}
\hline Gene ID & Species & $\mathrm{Db}$ & Genome location & $\begin{array}{l}\text { EST } \\
\text { no. }\end{array}$ & Tissue & $\begin{array}{c}\text { EST } \\
\text { total } \\
\text { no. }\end{array}$ \\
\hline cit.11563 & C. clementina & $\mathrm{H}, \mathrm{P}$ & $\begin{array}{c}\text { scaffold_9: } \\
\text { 2625370-2627369 }\end{array}$ & 26 & $\begin{array}{c}\text { Callus, seedling, leaf (healthy and subjected to biotic and abiotic } \\
\text { stress), mixed tissues }\end{array}$ & 558387 \\
\hline cit.5456 & C. clementina & $\mathrm{H}, \mathrm{P}$ & $\begin{array}{l}\text { scaffold_9: } \\
2630019-2630586\end{array}$ & 13 & $\begin{array}{l}\text { Root challenged with nematode or abiotic stresses, seedling, } \\
\text { callus, ovaries (abscission zone), cambium }\end{array}$ & 558387 \\
\hline cit.5776 & C. clementina & $\mathrm{H}, \mathrm{P}$ & $\begin{array}{l}\text { scaffold_9: } \\
\text { 2635345-2635854 }\end{array}$ & 6 & Roots with iron deficiency, seedling, CTV infected leaves & 558387 \\
\hline 29807.t000019 & R. communis & $\mathrm{P}$ & $\begin{array}{l}\text { 29807: } 160071- \\
160289\end{array}$ & 0 & & 62592 \\
\hline 29807.t000020 & R. communis & $P$ & $\begin{array}{l}\text { 29807: } 162893- \\
163060\end{array}$ & 0 & & 62592 \\
\hline 29807.t000021 & R. communis & $\mathrm{P}$ & $\begin{array}{l}\text { 29807: } 166312- \\
166566\end{array}$ & 0 & & 62592 \\
\hline POPTR_0005s09890 & P. trichocarpa & $P$ & $\begin{array}{l}\text { scaffold_5: } \\
\text { 6981801-6981953 }\end{array}$ & 1 & Bark challenged with insects & 163281 \\
\hline Medtr2g097910 & M. truncatula & $\mathrm{P}$ & $\begin{array}{l}\text { MtChr2: } 23065990- \\
\text { 23066574 }\end{array}$ & 0 & & 281422 \\
\hline Medtr2g097920 & M. truncatula & $P$ & $\begin{array}{l}\text { MtChr2: } 23068445- \\
23068814\end{array}$ & 1 & Virus-infected leaves & 281422 \\
\hline Medtr2g097930 & M. truncatula & $P$ & $\begin{array}{l}\text { MtChr2: } 23070933- \\
23071212\end{array}$ & 0 & & 281422 \\
\hline Medtr2g097940 & M. truncatula & $P$ & $\begin{array}{l}\text { MtChr2: } 23073825- \\
\quad 23074037\end{array}$ & 0 & & 281422 \\
\hline Medtr2g097960 & M. truncatula & $P$ & $\begin{array}{l}\text { MtChr2: } 23078947- \\
\quad 23079251\end{array}$ & 1 & Flowers, early seeds, late seeds and stems & 281422 \\
\hline Medtr7g104220 & M. truncatula & $P$ & $\begin{array}{l}\text { MtChr7: } 23576194- \\
\quad 23576346\end{array}$ & 0 & & \\
\hline Medtr7g104490 & M. truncatula & $P$ & $\begin{array}{l}\text { MtChr7: } 23711526- \\
\quad 23711678\end{array}$ & 0 & & 281422 \\
\hline AT1G47395 & A. thaliana & $P$ & $\begin{array}{l}\text { Chr1: } 17383034- \\
17383408\end{array}$ & 2 & Mixed library of flower, leaf and root & 1529700 \\
\hline AT1G47400 & A. thaliana & $P$ & $\begin{array}{l}\text { Chr1: } 17385717- \\
\quad 17386186\end{array}$ & 1 & Inflorescence & 1529700 \\
\hline asmbl_6543.p5arabi0 & A. thaliana & $P$ & $\begin{array}{c}\text { Chr1:17389096- } \\
17389541\end{array}$ & 37 & Mixed & 1529700 \\
\hline 923037 & A. lyrata & $P$ & $\begin{array}{c}\text { scaffold_1: } \\
\text { 23646793-23646985 }\end{array}$ & 0 & & 583 \\
\hline 923038 & A. lyrata & $P$ & $\begin{array}{c}\text { scaffold_1: } \\
\text { 23656301-23656493 }\end{array}$ & 0 & & 583 \\
\hline 923039 & A. lyrata & P & $\begin{array}{c}\text { scaffold_1: } \\
23659179-23659371\end{array}$ & 0 & & 583 \\
\hline 923040 & A. lyrata & $P$ & $\begin{array}{l}\text { scaffold_1: } \\
\text { 23667427-23667637 }\end{array}$ & 0 & & 583 \\
\hline 923041 & A. lyrata & $\mathrm{P}$ & $\begin{array}{c}\text { Scaffold_1: } \\
\text { 23669301-23669511 }\end{array}$ & 0 & & 583 \\
\hline 923042 & A. lyrata & $P$ & $\begin{array}{l}\text { Scaffold_1: } \\
\text { 23670810-23671020 }\end{array}$ & 0 & & 583 \\
\hline 923043 & A. lyrata & $P$ & $\begin{array}{c}\text { scaffold_1: } \\
\text { 23672121-23672332 }\end{array}$ & 0 & & 583 \\
\hline С6Т1M0 & G. $\max$ & U & $\begin{array}{l}\text { Gm05: } 8142747- \\
\quad 8142956\end{array}$ & 14 & $\begin{array}{c}\text { Mixed, root, cotyledon, leaf, seedlings treated with salicylic acid, } \\
\text { whole plant }\end{array}$ & 1461624 \\
\hline С6T2M5 & G. $\max$ & U & $\begin{array}{c}\text { Gm06: } 21775640- \\
21775813\end{array}$ & 7 & Mixed, mixed stressed tissues, root, pod, flower, tissue culture & 1461624 \\
\hline CGD0032389 & T. cacao & CGD & $\begin{array}{l}\text { super_9: } 9549794- \\
9550390\end{array}$ & 12 & Pod, wood, leaf, flower, cushion & 159996 \\
\hline CGD0032388_alt & T. cacao & CGD & $\begin{array}{l}\text { super_9: } 9552787- \\
\text { 9553408 }\end{array}$ & 2 & Leaves sprayed with the defense elicitors & 159996 \\
\hline
\end{tabular}


Table 2 Putative aspartic acid-rich (Asp-rich) protein genes found in different species, with information on the number of associated ESTs supporting their expression in different tissues, and total number of ESTs for each species (Continued)

\begin{tabular}{|c|c|c|c|c|c|c|}
\hline cassava4.1_020818m. & M. esculenta & $\mathrm{P}$ & $\begin{array}{l}\text { scaffold07478: } \\
\text { 525348-525861 }\end{array}$ & 6 & Mixed tissues from water stressed plant & 80631 \\
\hline DW225255 & G. hirsutum & G & & 3 & Stem, mixed (meristematic region, very young fiber, roots, stem) & 274247 \\
\hline JG443702 & $\begin{array}{c}\text { M. } \times \\
\text { domestica }\end{array}$ & G & & 10 & $\begin{array}{l}\text { Young leaves inoculated with Marssonina coronaria, flower, fruit, } \\
\text { bud, leaf }\end{array}$ & 324742 \\
\hline GD112635 & C. annuum & G & & 4 & Callus & 118060 \\
\hline BQ513915 & S. tuberosum & G & & 3 & Mixed & 249616 \\
\hline CV506984 & S. tuberosum & G & & 1 & Mixed floral & 249616 \\
\hline BP128846 & N. tabacum & G & & 1 & Cell culture & 332667 \\
\hline CK289672 & $\begin{array}{c}N \text {. } \\
\text { benthamiana }\end{array}$ & G & & 1 & $\begin{array}{l}\text { Abiotic and biotic stress-treated leaves, callus tissue and root } \\
\text { tissue }\end{array}$ & 56080 \\
\hline BI207662 & $\begin{array}{c}\text { S. } \\
\text { lycopersicum }\end{array}$ & G & & 2 & Suspension cultures & 299460 \\
\hline BJ560905 & I. nil & G & & 3 & Flowers and flower buds & 62282 \\
\hline GW342884 & C. sinensis & G & & 3 & Leaves induced by Ectropis obliqua feeding & 20,277 \\
\hline CV534433 & P. vulgaris & G & & 1 & Nodules & 116,836 \\
\hline AJ765027 & G. hybrida & G & & 1 & Flower organ (pappus bristles) & 16997 \\
\hline DN950726 & Q. robur & G & & 1 & Tissue culture growing 2 days in hypertonic medium & 81671 \\
\hline EX249889 & C. papaya & G & & 1 & Flowers after meiosis & 77393 \\
\hline CU434296 & $\begin{array}{c}\text { C. } \\
\text { hemisphaerica }\end{array}$ & G & & 1 & Not specified & 85991 \\
\hline CB289635 & V. aestivalis & G & & 3 & Leaves & 2101 \\
\hline DW174778 & L. virosa & G & & 1 & Mixed & 30068 \\
\hline FN002522 & P. $\times$ hybrida & G & & 2 & Roots, developing ovaries & 50705 \\
\hline GE593719 & $\begin{array}{c}\text { C. } \\
\text { cardunculus }\end{array}$ & G & & 1 & Green globe & 36323 \\
\hline
\end{tabular}

EST no. refers to ESTs found in dbEST database which typically showed query coverage and percentage of identity above $90 \%$. EST total no. refers to the total number of ESTs deposited in the dbEST database of NCBI until August 2011. Db refers to the database from which the information regarding the Asp-rich protein genes were retrieved. $\mathrm{H}$, Harvest database; P, Phytozome; G, GenBank; U, Uniprot; CGD, Cacao Genome Database

genes and DELLA, other predicted ORFs are present (Figure 5). The clusters of the four genomes share the main structure and gene orientation, with the presence of pentatricopeptide repeat (PPR) - containing proteins, an EamA-like nucleotide sugar transporter and an F-box gene located between the Asp-rich protein genes and DELLA. Not all the predicted genes are supported by expression data. The coding sequence of the F-box putative protein (represented by the grey box) upstream DELLA is not represented in the citrus GeneChip, and it has no significant similarity with the cit.7568 F-box.

\section{Histological and transcriptional changes during pollen- pistil interaction}

To investigate possible changes in mRNA levels during pollen germination and pollen tube elongation, a time course analysis was performed on whole styles with stigmas. We focused on the F-box-containing unigene cit.7568, which showed the highest fold change among the differentially expressed genes, and on the putative Asp-rich protein genes (cit.11563, cit.5456 and cit.5776). For this analysis, we collected non-pollinated flowers just prior to flowering (indicated as T0) as well as selfpollinated styles with stigmas from one to eight days after pollination (DAP), indicated as T1 to T8. Moreover, we investigated the expression patterns in non-pollinated flowers collected at T1, T3 and T6 to assess whether the genes were induced by pollination, or conversely, were developmentally regulated. A daily histological observation of self-pollinated styles with stigmas was performed on both varieties to monitor the rate of pollen tube elongation (Figure 6). This analysis was previously conducted on both genotypes [15]. However, since the pollen tube growth is highly influenced by environmental temperature, new microscopy observations were essential to detect possible coincidences between pollen tube behaviour of 'Comune' and 'Monreal' and transcriptional changes of the candidate genes. From T0 to T4, pistils of both varieties displayed similar performances regarding pollen tube germination and pollen tube elongation. Pollen germination was evident from T1 (Figure 6A-D), and until the $4^{\text {th }}$ DAP germinated tubes were at the level of the stigma (Figure 6BE), some of them reaching the upper style. Between T0 


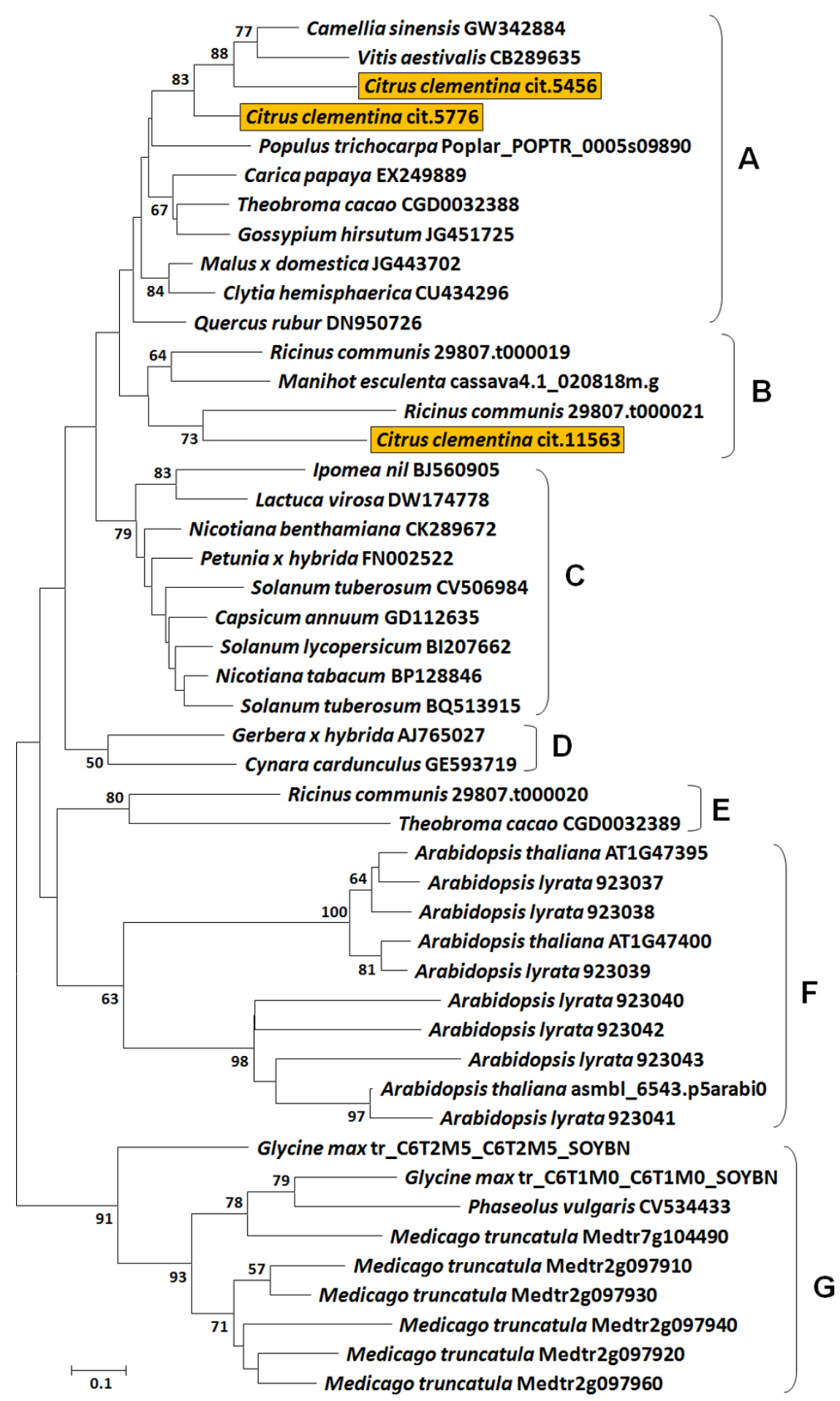

Figure 4 Phylogenetic analysis of the Asp-rich protein genes. The Neighbor joining tree based on p-distance and pairwise deletions of gaps shows phylogenetic relationship among the putative Asp-rich proteins identified in different species. The numbers at the branch points indicate bootstrap support values above 50\% (1,000 replicates). Based on Neighbor joining clustering, Asp-rich proteins were tentatively grouped into seven main families, from A to $\mathrm{G}$. The citrus Asp-rich proteins are highlighted. 


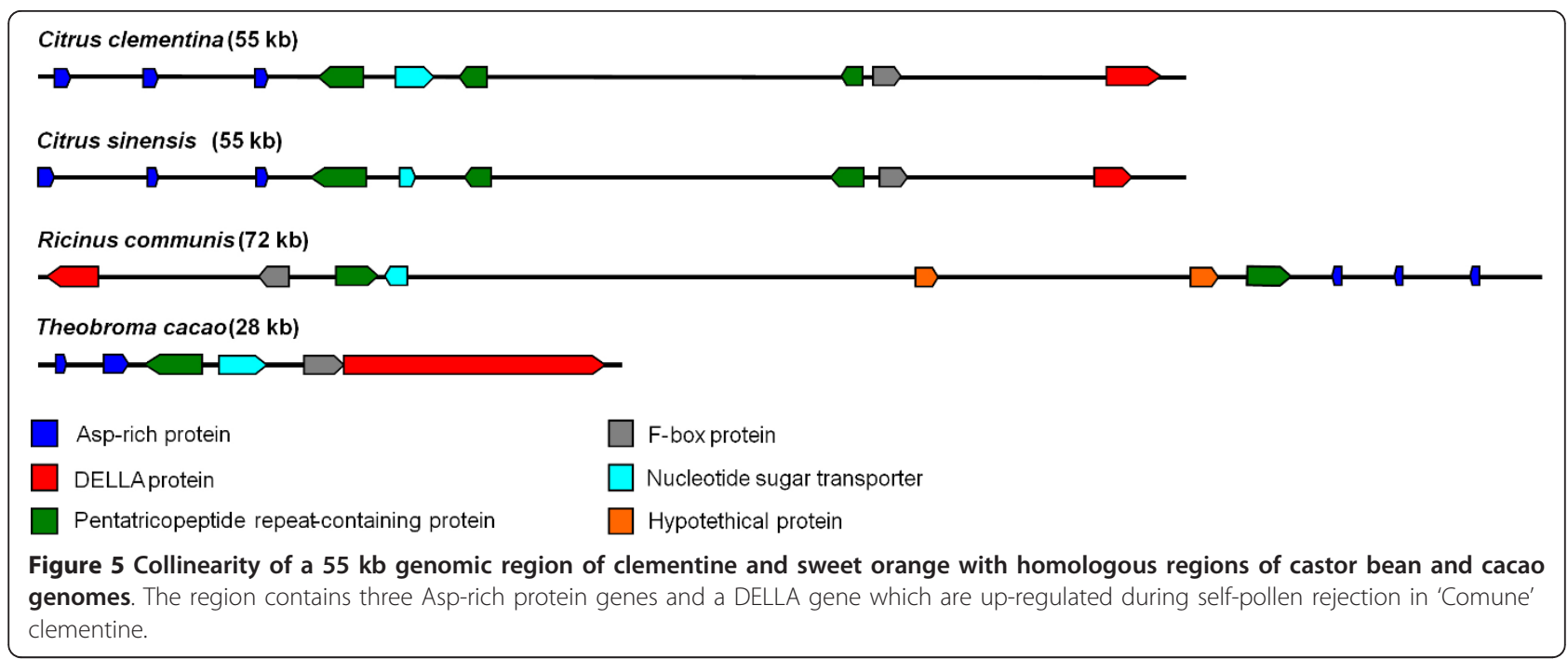

and T4, a slight up-regulation of all the analyzed transcripts was observed in 'Comune', although mRNA levels of the 4 genes were generally low (Figure 7). The exception is represented by cit.11563, which was already some 9 fold up-regulated in 'Comune' at T0. After T4 we observed a marked difference both in pollen tube kinetics and gene expression. In 'Comune', the selfincompatible genotype, pollen tubes were still in the

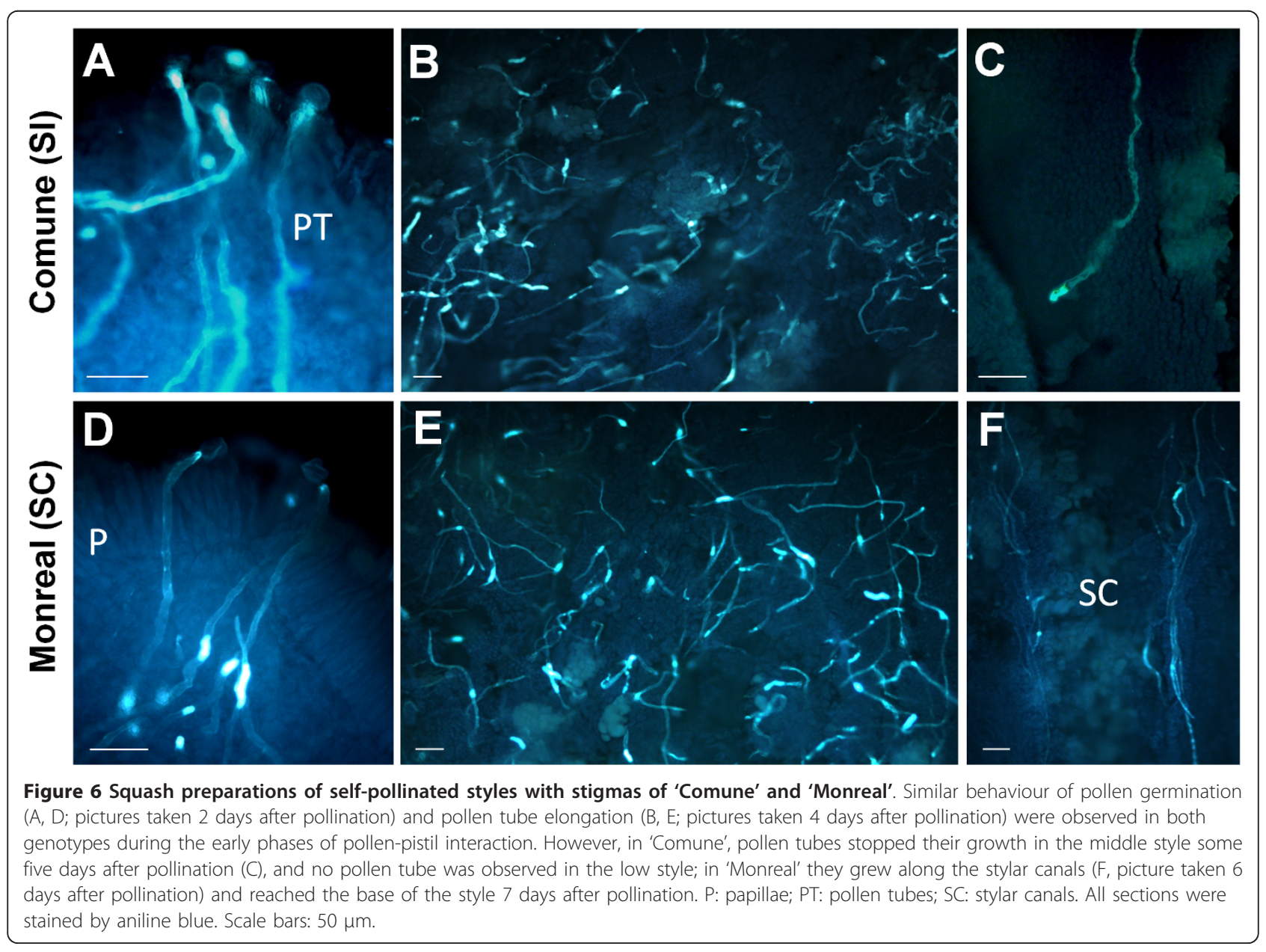




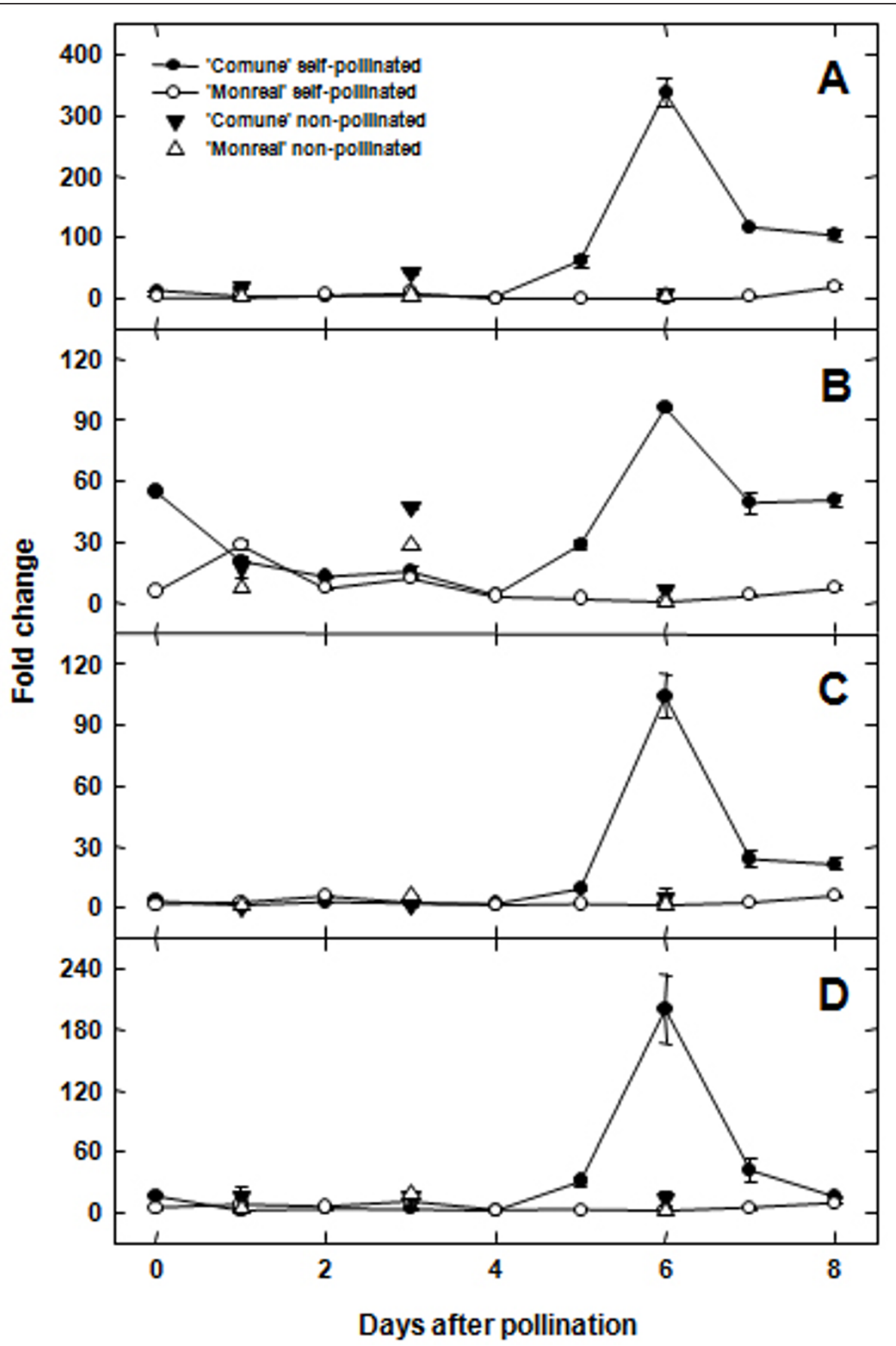

Figure 7 Relative gene expression of selected genes during pollen pistil-interaction. Genes are listed by their probe set ID of the Affymetrix Citrus GeneChip and by their tentatively assigned name. A: cit.7568 (F-box); B: cit.11563 (Asp-rich protein gene); C: cit.5456 (Asp-rich protein gene); D: cit.5776 (Asp-rich protein gene). Styles with stigmas were sampled from 0 (non-pollinated flowers) to 8 DAP. Control samples of non-pollinated flowers, collected at 1, 3 and 6 DAP, were added to the time course analysis to determine if the genes were induced by selfpollination. Error bars indicate standard deviations from the mean.

stigmatic canals, and only a few were recorded in the upper or middle style (Figure 6C). Conversely, in 'Monreal' a conspicuous number of pollen tubes grew along the middle style (Figure 6F), reaching the base of the style after 7 days. The differences in pollen tube behaviour coincided with differences in gene expression. From T5 a clear up-regulation of the 4 genes was observed in 'Comune', with a peak of expression at T6, 
while in 'Monreal' no changes were observed compared to the previous sampling dates (Figure 7). 'Comune' unpollinated flowers at T6 showed mRNA levels comparable to the ones of 'Monreal', indicating the selfincompatible condition elicited the up-regulation of the F-box and of the Asp-rich protein genes.

Additional qRT-PCR were performed on pollen tubes grown in vitro, to assess whether the different mRNA levels detected in the time course analysis might have been influenced by a differential expression at the level of pollen tubes. RNA was isolated from tubes grown for about $24 \mathrm{~h}$, which showed similar rate of elongation between the two clementines (Figure 8A). Extremely low mRNA levels and no differential expression were observed in cit.7568, cit.11563 and cit.5456 (Figure 8B), while no expression was detected for cit.5776. The time course analysis was also performed to analyze the expression patterns of DELLA, which was preferentially expressed in 'Comune' styles with stigmas at T6 and T7 (Additional file 2).

\section{Discussion}

In this study, LCM was used to spefically isolate SCC of two clementine genotypes differing for the SI response.

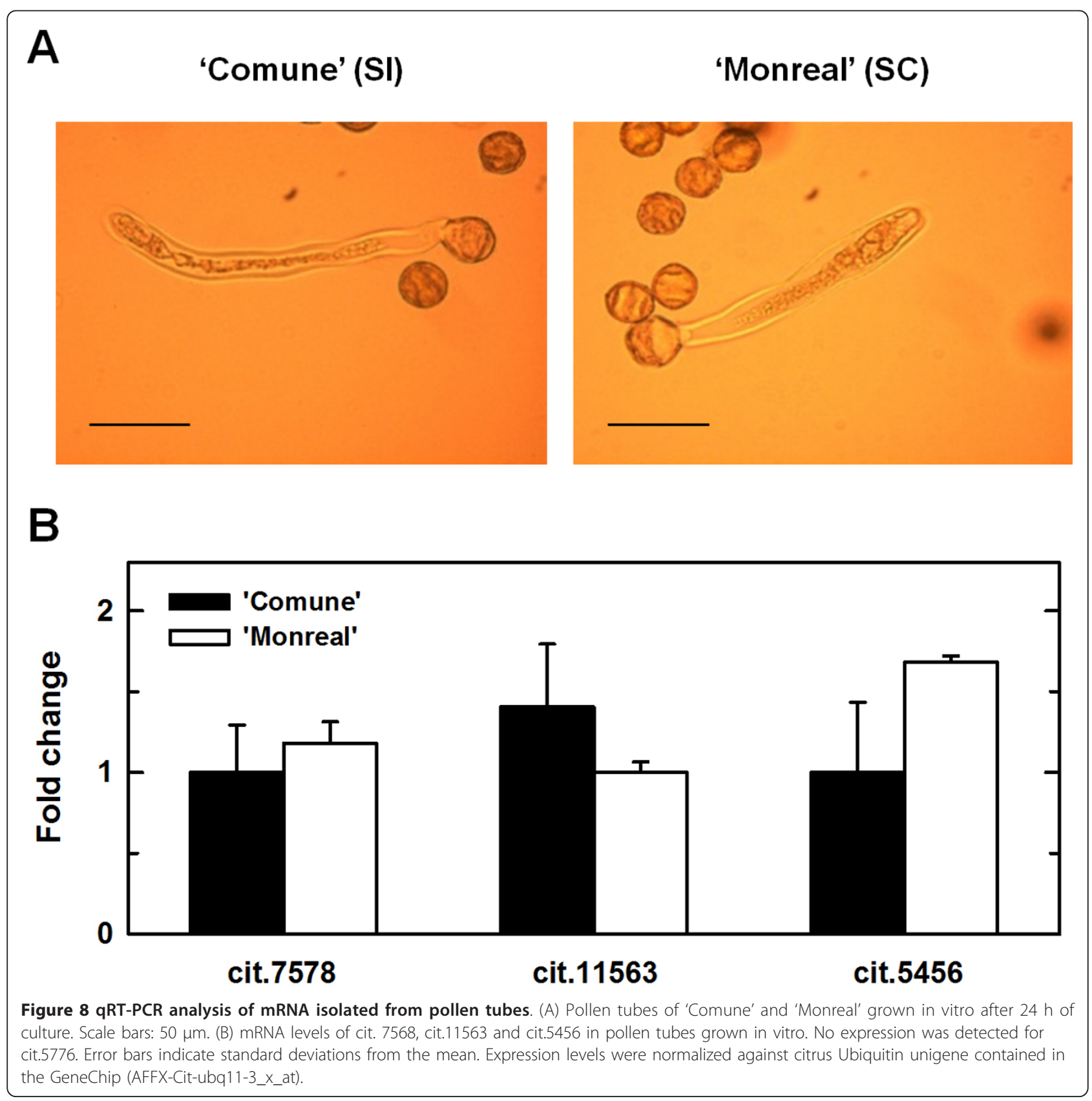


'Comune' is a widespread self-incompatible variety, while 'Monreal' is a self-compatible variety originated from a spontaneous bud mutation [17]. The microdissection of the SCC allowed to perform a highly specific study of the transcriptome of the cells implicated in the interaction between pistil and pollen tubes, with the main aim of identifying candidate genes involved in selfpollen rejection. The results of microarray analysis suggested that the differential regulation of few specific transcripts might have lead to the breakdown of SI in 'Monreal'. Based on functional information retrieved from the databases, these genes do not show any clear functional enrichment, and many of them have no annotation, making it difficult to compare our results with SI systems characterized on model plants. On the other hand, our experiment provided a new set of transcripts that are very likely to play a key role during the progamic phase in citrus. Searches in the databases revealed that most of these genes are not flower specific, suggesting that probably the mutation leading to the breakdown of SI did not affected the S-locus determinants. However, it is known that non S-locus genes are implicated in SI [30]. Most of the preferentially expressed genes were low-represented in EST databases and showed a weak expression in whole styles with stigmas before the SI reaction occurred. This indicates the usefulness of the LCM in the identification of highly specific and/or low expressed genes.

Flowers for LCM were sampled one day after pollination, when pollen was just germinating. Self-pollinations were performed to assess whether the presence of pollen in the stigma might have elicited a differential response of the SCC in self-compatible vs. self-incompatible conditions. So, while pollen tubes where still in the stigma, we targeted the rectangular SCC located in the upper/middle style, which is the site where incompatibility occurs in 'Comune', without contamination of pollen tubes. Although we did not analyze mRNAs of microdissected SCC of non-pollinated flowers, qRT-PCR demonstrated that slight differences in gene expression were also present in whole styles with stigmas before pollination, indicating that, at least in the cases of cit.7568, cit.11563, cit.5456 and cit.5776, the different mRNA levels in the SCC between 'Comune' and 'Monreal' were not induced by the pollen germination in the stigma.

Among the identified genes, our analysis focused on four unigenes over-represented in 'Comune' (cit.7568, cit.11563, cit.5456 and cit.5776). A time course analysis coupled to histological observation of pollen tube elongation was performed to correlate pollen tube behaviour with the difference in gene expression between 'Comune' and 'Monreal'. Until the 4th DAP we could not observe any clear differences in the mRNA level of the 4 analyzed genes, and no clear differences were evident in pollen tube behaviour between the two varieties. Form the $5^{\text {th }}$ DAP we observed an impressive up-regulation in the self-incompatible combination. Selected candidate genes showed a clear differential expression (even $>100$ fold change) during pollen - style interaction (Figure 7), in agreement with histological observation (pollen tube growth in 'Monreal' and no growth in 'Comune'). The peak of up-regulation was evidenced in concomitance with the pollen tube arrest, suggesting that all the analyzed genes have a key role in the stop of pollen tube elongation. The up-regulation was clearly induced by pollen tubes in the styles, as confirmed with the comparison of the expression levels of non-pollinated and self-pollinated flowers at T6 (Figure 7). The candidate genes were weakly expressed in pollen tubes and no differences in the mRNA levels were observed between 'Comune' and 'Monreal' (Figure 8). As a result, it is unlikely that the transcriptome of pollen tubes influenced the mRNA levels detected in the time course analysis. In fact, our expression data demonstrate that the drastic changes in mRNA levels occurred in the stylar tissues as a response to self-incompatible pollen tubes. Also, the drastic upregulation of the four genes should not represent a downstream response to SI, since these genes are already differentially regulated in SCC before SI occurs.

Bioinformatic analysis provided useful information to hypothesize the role of the four unigenes. cit.7568 probe set matched to a putative F-box protein gene sharing homology to an Arabidopsis F-box (At5g04010) annotated as non-specific [28]. This protein belongs to the C2 group of the F-box superfamily, of which SLY1 belongs. However, the similarity with SLY1 regards the F-box domain, while the C-terminus, responsible for targeting the substrate for ubiquitination, does not share any homology with SLY1.

F-box protein superfamily is one of the largest in plants $[31,32]$. These proteins are key regulators of proteolysis, conferring specificity to the SCF (Skp1, Cullin, F-box) E3 ubiquitin ligase complex, which is responsible for recognizing the substrate for ubiquitin-mediated protein degradation. Despite the fact that it is not possible to correlate the role of the novel clementine F-box gene with any characterized orthologs, database searches and transcriptional data revealed that the clementine F-box gene was not previously identified in clementine cDNA libraries and evidenced highly specific expression patterns, since it was almost 250 fold up-regulated in SCC (Figure 2) and about 50 to 300 fold up-regulated in whole styles with stigmas (Figure 7A) in concomitance with the arrest of pollen tube elongation. This drastic upregulation, and the absence of identical ESTs in databases support the high specificity of this gene and point out to its possible involvement in highly specific proteolytic events occurring in the style during the self-incompatible 
response. Studies on the families where SI system have been already characterized (namely Brassicaceae, Solanaceae and Papaveraceae) showed that proteolysis has a key role during self-pollen rejection. Usually proteolytic events follow the initial SI signal perception leading to the eventual death of the male gametophyte [33]. Functional analysis will be necessary to shed light on the role of the clementine F-box during pollen-pistil interaction.

Another striking finding was the identification of the three putative Asp-rich protein encoding genes, cit.11563, cit.5456 and cit.5776, up regulated in 'Comune'. In addition to the high similarity in their primary structure, they co-localize in the clementine genome (Figure 5). The clustered genes displayed similar expression patters (Figure 7B, C, D) which might indicate that they are commonly regulated as already reported for other clusters [34,35]. Although their function has not been investigated, it is known that the expression of the Arabidopsis homologous At1g47400 is sharply up regulated in plants exposed to 3-(30,40-dihydroxyphenyl)-Lalanine (L-DOPA), a phytotoxic allelochemical [36]. In other studies, this gene turns out to be strongly induced by iron deficiency [37] and by treatment with the polycyclic aromatic hydrocarbon phenanthrene [38]. These results support the hypothesis that the genes encoding the Asp-rich proteins might be triggered in response to different types of stresses. Since other information is still lacking, we attempt to assign a putative function to the Citrus Asp-rich proteins and also propose a model which overall might explain the regulation of SI in the 'Comune' variety. Because of their richness of aspartic acid residues, the Asp-rich proteins are supposed to act as novel $\mathrm{Ca}^{2+}$ "entrapping" proteins. Although they do not show sequence similarity with other well known $\mathrm{Ca}^{2+}$ interacting proteins, such as calsequestrin, calreticulin and calmodulin, the Asp-rich proteins share with those proteins the aspartate residue abundance which has been related with the protein ability of $\mathrm{Ca}^{2+}$-binding [39]. Therefore, assuming that $\mathrm{Ca}^{2+}$ levels play a decisive role during pollen-pistil interaction, as already reported for several plant species [40], the up-regulation of the Asp-rich encoding genes observed in 'Comune' might enhance the amount of proteins functioning as $\mathrm{Ca}^{2+}$-trap elements, and lead to an exceptional decrease in $\mathrm{Ca}^{2+}$ availability, thus contributing to switch off the signal cascade usually induced by the increase in cytosolic $\mathrm{Ca}^{2+}$ concentration or to the alteration of $\mathrm{Ca}^{2+}$ gradient needed for pollen tube elongation. Pollen tube growth could represent, among others, the downstream physiological process dramatically affected by this missing triggering event. To support this hypothesis, it is worthwhile to mention that the aforesaid At1g47400 gene is up regulated in a T-DNA insertional mutant of a P-type ATPase cation pump, the MALE GAMETOGENESIS IMPAIRED ANTHERS (MIA); the mutant shows reduced male fertility and imbalanced cation homeostasis [41]. Moreover, a $\mathrm{Ca}^{2+}$ pump (autoinhibited $\mathrm{Ca}^{2+}$-ATPase - ACA), which presumably pumps $\mathrm{Ca}^{2+}$ out the cytosol [42], is differentially regulated in the two genotypes during pollen-pistil interaction showing an up regulation in the 'Comune' genotype [15]. Further mandatory work will be undertaken to validate both the supposed role and the functioning model of pollen-pistil interaction in Citrus genotypes and, if they are proved, this might represent a case in which specific regulatory mechanism involving different loci rather than the $S$-locus could be co-responsible of the SI determination.

The integration of the transcriptomic data with the synteny analysis denoted a specific genome region containing a cluster of genes activated during self-pollen rejection (Figure 5). Specifically, the Asp-rich protein genes are linked to a DELLA gene which was previously isolated in the self-pollinated 'Comune' styles with stigmas [15] and showed a preferential expression in the self-incompatible genotype. This raise intriguing questions about the possibility that the non-homologous genes located in this genome region might contribute to a common function related to self-pollen rejection. Examples of co-expressed and functionally related gene clusters in eukaryotes have emerged over the last decade $[34,43]$ and are likely to increase with the huge amount of data coming from the genome projects. The most investigated operon-like organizations in plants are secondary metabolic pathways [44], mostly implicated in plant defence response. Clustering appears to have occurred de novo through some form of convergent evolutionary process [43]. In our case, it is unlikely that the genes are clustered by chance, since this cluster is conserved in at least two other plant species, cacao and castor bean (Figure 5). The collinearity of the citrus genome segment comprising the Asp-rich protein genes and DELLA with other segments of unrelated genomes support the hypothesis that selection might have favoured the linkage of these genes. The advantage of clustering is related with the fact that tightly linked genes might be co-regulated at the levels of nuclear organization and/or chromatin [43,45]. The co-localization of the three up-regulated Asp-rich protein genes as well as DELLA in the scaffold 9 of the clementine genome v0.9 suggests that the mutation leading to self compatibility probably affected the functionality of tightly linked genes. Further transcriptional analyses will be carried out on the other genes surrounding the Asp-rich protein genes to study their possible role during different stages of the pollen-pistil interaction.

\section{Conclusion}

LCM coupled to microarray analysis was definitely a powerful tool to identify candidate genes involved in self 
pollen rejection which have not been previously associated to SI. Data at the transcriptome level strongly suggested that a restricted number of differentially regulated transcripts are associated with self-pollen recognition. Although functional information is missing, we hypothesize that proteolysis and $\mathrm{Ca}^{2+}$ homeostasis might be crucial for SI response in clementine, reflecting to some extent molecular events occurring in other SI systems. However, further work at the protein level will be necessary for understanding the role of the candidate genes during self-pollen recognition. Also, the unigenes represented in the GeneChip do not cover the whole transcriptome, consequently other strategies such as RNA-seq might help to improve the transcriptome coverage to identify additional genes implicated in self-pollen recognition.

\section{Methods}

Plant material

Plant material was collected from adult trees of 'Comune' clementine and its self-compatible natural mutation 'Monreal', grown at the experimental station of Consiglio per la Ricerca e la sperimentazione in Agricoltura (CRA) placed in Palazzelli, Lentini (SR), Italy.

\section{Laser microdissection of SCC}

Styles with stigmas, collected 24 hours after self-pollination, were immediately snap-frozen in OCT embedding medium (Sakura Finetek, Zoeterwoude, Netherlands) in Peel-A-Way plastic embedding molds (Polysciences, Polysciences, Warrington, PA, USA). The embedded samples were stored at $-80^{\circ} \mathrm{C}$ until used. Transversal sections $10 \mu \mathrm{m}$ thick at the upper part of the style were cut with a Leica CM1900 cryostat (Leica Microsystems, Germany) at $-20^{\circ} \mathrm{C}$. Cryosections were mounted on PET-membranecoated stainless steel slides (Leica Microsystems, Wetzlar, Germany) and processed as described previously [46]. Each slide contained 15-20 style sections. A Leica AS Laser Microdissection system (Leica Microsystems) was used for the isolation of stylar canals from transversal sections. Canals from the stigma were discarded to avoid contamination with pollen or pollen tubes. Microdissection was performed using the X40 magnification lens with the following settings: aperture: 6; intensity: 46; speed: 2; offset: 40; bridge: medium. SCC were collected in the cap of a $0.5 \mathrm{ml}$ microtube filled with RLT buffer from the RNeasy Plus Micro Kit (Qiagen, Hilden, Germany).

\section{RNA isolation and amplification}

Three biological replicates were prepared for each genotype. Each biological replicate consisted of bulks of about 200 microdissected areas (composed of an average of 50 cells) coming from two different molds. RNA isolation was performed from $\sim 10,000$ cells using the
RNeasy Micro Kit (Qiagen) following the manufacturer's instructions. RNA samples were subjected to a tworound amplification TargetAmp ${ }^{\mathrm{TM}}$ 2-Round BiotinaRNA Amplification Kit 3.0 (Epicentre Biotechnologies, Madison, WI, USA) following the manufacturer's instructions. Quality of the aRNAs was assayed by OD260/OD280 measurements, agarose gel electrophoresis and Agilent 2100 Bioanalyzer.

\section{Microarray analysis}

Microarray experiments were performed using the GeneChip ${ }^{\circledR}$ Citrus Genome Array (Affymetrix, Santa Clara, CA, USA). Ten micrograms of biotynilated aRNA were used for the chip hybridizations. Data obtained from the microarray experiment were processed using Robin [47], which consists in an easy to use graphical interface for microarray analysis functions from R/BioConductor. CEL files were normalized by Robust Multi-Array Analysis (RMA) method. All microarray data have been deposited in the Gene Expression Omnibus (GEO) database under accession GSE33014. The list of probe sets showing significant differential expression was calculated comparing the three replicates for each genotype using Rank Products method [25]. Percentage of false-positives (PFP) cut-off, corresponding to the false discovery rate, was set at 0.06 and calculated based on 100 permutations. Probe set information was retrieved from Harvest: Citrus database http:// harvest.ucr.edu, http://www.harvest-web.org. Differentially expressed unigenes were subjected to Basic Local Alignment Search Tool (BLAST) search against the GenBank NR database. Interproscan http://www.ebi.ac.uk/Tools/ InterProScan/ was used to identify conserved domains in the deduced protein sequences.

\section{Validation of differentially expressed genes}

Two RNA isolations (one for each genotype) were performed from additional bulks of SCC for the validation of microarray results. Each RNA was extracted from 10,000 cells and amplified using TargetAmp ${ }^{\mathrm{TM}}$ 2-Round aRNA Amplification Kit 2.0 to generate unlabeled aRNA. Quality of the aRNAs was assayed by OD260/OD280 measurements and agarose gel electrophoresis. cDNA was synthesized from 500 ng aRNA using the Ready-to-go RT-PCR beads (GE Healthcare Technologies, Little Chalfont, UK) with primer dT. Before performing qRT-PCR, an RT-PCR was carried out to check the presence of possible unspecific products. The transcript levels were determined by real-time quantitative RT-PCR (qRT-PCR) using the ABI Prism 7000 Sequence Detection System (Applied Biosystems, Foster City, CA, USA) and the Power SYBR Green PCR Master Mix as previously described [15]. Real time was performed using three cDNA synthesis for each genotype, and each amplification was repeated twice. Primers used are listed in the Additional file 3. Primer pairs that 
did not reveal single dissociation peak were discarded. mRNA levels were calculated by standard-curve with a 5fold dilution series and normalized against citrus Ubiquitin unigene contained in the GeneChip (AFFX-Cit-ubq113_x_at).

\section{Histological observations}

Ten self-pollinated flowers for each genotype were collected every 24 hours from the first to the eighth day after pollination to monitor pollen germination and pollen tube kinetics. Squash preparations and microscopy observation were performed as described in Distefano et al. [15].

\section{Time course analysis}

Selfed 'Comune' and 'Monreal' styles with stigmas were collected from 0 (virgin flowers) to 8 DAP. To check whether the expression patterns were influenced by pollen-pistil interaction, control samples of non-pollinated flowers were collected at 1, 3 and 6 DAP. Bulks of about 25 styles with stigmas were immediately stored in liquid nitrogen after collection and were used for total RNA isolation using RNeasy Plant Mini Kit according to the product manual (Qiagen). Total RNA was treated with RNase-Free DNase set (Qiagen) according to the manufacturer's instructions. Total RNA was amplified by PCR to confirm the absence of genomic DNA in the samples. cDNA synthesis was carried out starting from $2 \mu \mathrm{g}$ total RNA. Real time runs and the data analysis were performed as described above. Two biological replicates were used for each sampling date, and all amplifications were repeated twice. Time course was carried out to evaluate expression patterns of 4 unigenes preferentially expressed in 'Comune' (probe set names cit.7568, corresponding to the SLY-like F-box gene; and cit.11563, cit. 5456, cit.5776, corresponding to the putative Asp-rich protein genes) as well as of a DELLA gene previously isolated by cDNA-AFLP from 'Comune' selfpollinated styles with stigmas [GenBank: GH733267].

\section{In vitro pollen tube germination and RNA isolation}

About 30 flowers were collected just before anthesis and their petals and pistils were removed. The anthers were left to dehisce for $24 \mathrm{~h}$ at room temperature. The fresh pollen was cultured in Petri dishes in the liquid pollen germination and tube growth medium described by Mesejo et al. [48]. After 24 h of culture, pollen tubes were pelleted by centrifugation and harvested for RNA isolation using RNeasy Plant Mini Kit (Qiagen).

\section{Similarity searches and phylogenetic analysis of the Asp- rich protein genes}

DNA sequences of citrus unigenes corresponding to the Asp-rich protein were blasted against the sequenced genomes available at the Phytozome website $v 7.0$ http://www.phytozome.net. Other sequences of Asp-rich homologs were retrieved from GenBank, Uniprot and the Cacao Genome Database http://www.cacaogenomedb.org.

ORF prediction was based on the genome browser data for each analyzed species as well as Fgenesh analysis http://www.softberry.com. All the predicted protein sequences (3 citrus Asp-rich plus 44 from other species) were aligned by ClustalX [29]. Alignments were analyzed using Mega 5 package [49] and a phylogenetic tree based on p-distance and pairwise deletions of gaps was constructed using the neighbor joining method with 1,000 bootstrap replicates.

\section{Identification of the cit.7568 F-box functional allele}

A 1,448 bp fragment that span the cit.7568 locus was amplified in both genotypes using the primers provided in the Additional file 3. The region was divided in three PCR products, which were cloned into pGem-T Easy Vector (Promega, Madison, WI, USA) and sequenced, or directly sequenced, using an ABI310 genetic analyzer (Applied Biosystems). The sequence of the region spanning the cit.7568 locus was deposited in the NCBI GenBank database [GenBank: JN885720].

\section{Additional material}

Additional file 1: Agilent 2100 Bioanalyzer profiles of amplified RNAs (aRNAs). Profiles show the size distribution of aRNAs produced from the different biological replicates after two rounds of amplification. Top central, RNA size marker ladder (RNA 6000 Ladder, Applied Biosystems). On the right of each electropherogram is a gel image generated from aRNAs with a smear ranging from 200 to $2000 \mathrm{bp}$ and a peak around $600 \mathrm{bp}$

Additional file 2: Real time expression patterns of DELLA gene during pollen-pistil interaction in the self-compatible ('Monreal') and the self-incompatible ('Comune') genotypes.

Additional file 3: List of primer pairs used for the real time quantitative RT-PCR analysis and for sequencing.

\section{Abbreviations}

aRNA: Amplified RNA; Asp-rich: Aspartic acid-rich; DAP: Day(s) after pollination; EST: Expressed sequence tag; LCM: Laser capture microdissection OCT: Optimal cutting temperature; ORF: Open reading frame; qRT-PCR: Real time quantitative RT-PCR; RP: Rank products; SCC: Stylar canal cells; SI: Selfincompatibility; SLY1: SLEEPY.

\section{Acknowledgements}

We thank Dr. Giuseppina Las Casas, Sergio Currò, Nicoletta Zingale for technical assistance, and Dr. Giuseppe Russo (CRA-ACM) who gave us the possibility to work at the Palazzelli experimental station. This work was supported by: the Italian Ministry of the University - Project PRIN "The productive process in fruit tree species: molecular, physiological and agronomical aspects of floral incompatibility and strategies for its control"; Regione Siciliana - Project "Risorse Genetiche Vegetali Sicilia". Work at the Centro de Genómica (IVIA) was supported by the Spanish Ministerio de Ciencia e Innovación-FEDER grant PSE-060000-2009-008 and the INIA grant RTA 2008-00065-00-00. 


\section{Author details}

'Dipartimento di Scienze delle Produzioni Agrarie e Alimentari, Università degli Studi di Catania, Via Valdisavoia 5, 95123 Catania, Italy. ${ }^{2}$ Institut Valencià d'Investigacions Agràries - Centre de Genómica, Carretera Montcada de I'Horta-Náquera Km. 4,5, 46113 Montcada de l'Horta (València), Spain.

\section{Authors' contributions}

$M C$ performed LCM, RNA extractions and amplifications, microarray analysis, qRT-PCR validation of differentially expressed genes, time course analysis, microscopy observations, in vitro pollen germination assay, bioinformatics and phylogenetic analyses, and drafted the manuscript. PM optimized and assisted LCM and RNA amplification experiments. GD carried out samplings and tissue embedding for LCM analysis, assisted QRT-PCR analyses and microscopy observations. ARLP performed and supervised bioinformatic analyses, helped in the interpretation of the results and participated in the draft of the manuscript. SLM assisted experimental design and helped draft the manuscript. FRT conceived the overall research, designed and funded LCM and aRNA experiments, assisted microarray analysis and phylogenetic analysis of the Asp-rich protein encoding genes, and participated in the draft of the manuscript. MT and AG coordinated, supervised and funded the experiments, and critically revised the manuscript. All authors have read and approved the final manuscript.

\section{Received: 7 December 2011 Accepted: 14 February 2012}

Published: 14 February 2012

\section{References}

1. Ollitrault P, Froelicher Y, Dambier D, Luro F, Yamamoto M: Seedlessness and ploidy manipulation. In Citrus Genetics, Breeding and Biotechnology. Edited by: Khan IA. Wallingford: CABI; 2007:197-218.

2. Soost RK: Incompatibility alleles in the genus Citrus. Proc Amer Soc Hort Sci 1965, 87:176-180.

3. Distefano G, Las Casas G, La Malfa S, Gentile A, Tribulato E, Herrero M: Pollen tube behavior in different mandarin hybrids. J Amer Soc Hort Sci 2009, 134:583-588

4. Ngo BX, Kim JH, Wakana A, Isshiki S, Mori T: Estimation of selfincompatibility genotypes of citrus cultivars with Got-3 allozyme markers. J Japan Soc Hort Sci 2011, 80:284-294.

5. Gentile A, Antognoni F, lorio RA, Distefano G, Las Casas G, La Malfa S, Serafini-Fracassini D, Del Duca S: Polyamines and transglutaminase activity are involved in compatible and self-incompatible pollination of Citrus grandis. Amino Acids 2012, 42:1025-1035.

6. Di Sandro A, Del Duca S, Verderio E, Hargreaves A, Scarpellini A, Cai G, Cresti M, Faleri C, lorio RA, Hirose S, Furutani Y, Coutts IGC, Griffin M, Bonner PLR, Serafini-Fracassini D: An extracellular transglutaminase is required for apple pollen tube growth. Biochem J 2010, 429:261-271.

7. Chai $L, G e X X, X u$ Q, Deng XX: CgSL2, an S-like RNase gene in 'Zigui shatian' pummelo (Citrus grandisOsbeck), is involved in ovary senescence. Mol Biol Rep 2011, 38:1-8.

8. Miao HX, Qin YH, Teixeira-da-Silva JA, Ye ZX, Hu GB: Cloning and expression analysis of S-RNase homologous gene in Citrus reticulato Blanco cv. Wuzishatangju. Plant Sci 2011, 180:358-367.

9. Ríos G, Naranjo MA, Iglesias DJ, Ruiz-Rivero O, Geraud M, Usach A, Talón M: Characterization of hemizygous deletions in Citrus using arraycomparative genomic hybridization and microsynteny comparisons with the poplar genome. BMC Genomics 2008, 9:381.

10. Alos E, Roca M, Iglesias DJ, Minguez-Mosquera MI, Damasceno CMB, Thannhauser TW, Rose JKC, Talon M, Cercos M: An evaluation of the basis and consequences of a stay-green mutation in the navel negra citrus mutant using transcriptomic and proteomic profiling and metabolite analysis. Plant Physiol 2008, 147:1300-1315.

11. Ríos G, Naranjo MA, Rodrigo MJ, Alós E, Zacarías L, Cercós M, Talón M: Identification of a GCC transcription factor responding to fruit colour change events in citrus through the transcriptomic analyses of two mutants. BMC Plant Biol 2010, 10:276.

12. Talon M, Cercos M, Iglesias DJ, Colmenero-Flores JM, Ibáñez V, Brumos J, Herrero-Ortega MA, Rios G, Terol J, Tadeo FR: Citrus genomics and breeding: identification of candidate genes by the use of mutants and microarrays. Acta Hort 2011, 892:19-25.

13. Honsho C, Kotsubo M, Fukuda Y, Hamabata Y, Kurogi Y, Nishiwaki A, Tetsumura T: Reproductive Characteristics for Self-compatibility and
Seedlessness in 'Nishiuchi Konatsu', a Bud Mutation of Hyuganatsu (Citrus tamurana hort. ex Tanaka). HortSci 2009, 44:1547-1551.

14. Ye WJ, Qin YH, Ye ZX, Teixeira-da-Silva JA, Zhang LX, Wu XY, Lin SQ, Hu GB: Seedless mechanism of a new mandarin cultivar 'Wuzishatangju'(Citrus reticulata Blanco). Plant Sci 2009, 177:19-27.

15. Distefano G, Caruso M, La Malfa S, Gentile A, Tribulato E: Histological and molecular analysis of pollen-pistil interaction in clementine. Plant Cell Rep 2009, 28:1439-1451.

16. Chai $\amalg$, Ge XX, Biswas MK, Xu Q, Deng XX: Self-sterility in the mutant 'Zigui shatian' pummelo (Citrus grandis Osbeck) is due to abnormal post-zygotic embryo development and not self-incompatibility. Plant Cell Tiss Org 2011, 104:1-11.

17. Hodgson RW: Horticultural varieties of citrus. In Citrus industry. Volume 1. Edited by: Reuther W, Webber HJ, Batchelor LD. Berkeley: University of California Press; 1967:431-591

18. Suwabe K, Suzuki G, Takahashi H, Shiono K, Endo M, Yano K, Fujita M, Masuko H, Saito H, Fujioka T, Kaneko F, Kazama T, Mizuta Y, KawagishiKobayashi M, Tsutsumi N, Kurata N, Nakazono M, Watanabe M: Separated transcriptomes of male gametophyte and tapetum in rice: validity of a laser microdissection (LM) microarray. Plant Cell Physiol 2008, 49:1407-1416.

19. Hobo T, Suwabe K, Aya K, Suzuki G, Yano K, Ishimizu T, Fujita M, Kikuchi S, Hamada K, Miyano M, Fujioka T, Kaneko F, Kazama T, Mizuta Y, Takahashi H, Shiono K, Nakazono M, Tsutsumi N, Nagamura Y, Kurata N, Watanabe M, Matsuoka M: Various spatiotemporal expression profiles of antherexpressed genes in rice. Plant Cell Physiol 2008, 49:1417-1428.

20. Tang X, Zhang ZY, Zhang WJ, Zhao XM, Li X, Zhang D, Liu QQ, Tang WH: Global gene profiling of laser-captured pollen mother cells indicates molecular pathways and gene subfamilies involved in rice meiosis. Plant Physiol 2010, 154:1855-1870.

21. Wuest SE, Vijverberg K, Schmidt A, Weiss M, Gheyselinck J, Lohr M, Wellmer F, Rahnenfuhrer J, von Mering C, Grossniklaus U: Arabidopsis female gametophyte gene expression map reveals similarities between plant and animal gametes. Curr Biol 2010, 20:506-512.

22. Ciampolini F, Cresti M, Sarfatti G, Tiezzi A: Ultrastructure of the stylar canal cells of Citrus limon (Rutaceae). Plant Syst Evol 1981, 138:263-274.

23. Distefano G, Gentile A, Herrero M: Pollen-pistil interactions and early fruiting in parthenocarpic citrus. Ann Bot 2011, 108:499-509.

24. Aprile A, Federici C, Close TJ, De Bellis L, Cattivelli L, Roose ML: Expression of the H+-ATPase AHA10 proton pump is associated with citric acid accumulation in lemon juice sac cells. Funct Integr Genomics 2011, 11:551-563.

25. Breitling $R$, Armengaud $P$, Amtmann A, Herzyk P: Rank products: a simple, yet powerful, new method to detect differentially regulated genes in replicated microarray experiments. FEBS Lett 2004, 573:83-92.

26. Casson S, Spencer M, Walker K, Lindsey K: Laser capture microdissection for the analysis of gene expression during embryogenesis of Arabidopsis. Plant J 2005, 42:111-123.

27. Hong F, Breitling R: A comparison of meta-analysis methods for detecting differentially expressed genes in microarray experiments. Bioinformatics 2008, 24:374-382.

28. Dill A, Thomas SG, Hu J, Steber CM, Sun TP: The Arabidopsis F-box protein SLEEPY1 targets gibberellin signaling repressors for gibberellin-induced degradation. Plant Cell 2004, 16:1392-1405.

29. Larkin MA, Blackshields G, Brown NP, Chenna R, McGettigan PA, McWilliam H, Valentin F, Wallace IM, Wilm A, Lopez R, Thompson JD, Gibson TJ, Higgins DG: Clustal W and Clustal X version 2. 0. Bioinformatics 2007, 23:2947-2948.

30. Kondo K, Yamamoto M, Itahashi R, Sato T, Egashira H, Hattori T, Kowyama Y: Insights into the evolution of selfcompatibility in Lycopersicon from a study of stylar factors. Plant J 2002, 30:143-153.

31. Gagne JM, Downes BP, Shiu SH, Durski AM, Vierstra RD: The F-box subunit of the SCF E3 complex is encoded by a diverse superfamily of genes in Arabidopsis. Proc Natl Acad Sci USA 2002, 99:11519-11524.

32. Kuroda H, Takahashi N, Shimada H, Seki M, Shinozaki K, Matsui M: Classification and expression analysis of Arabidopsis F-box containing protein genes. Plant Cell Physiol 2002, 43:1073-1085.

33. Zhang Y, Zhao Z, Xue Y: Roles of proteolysis in plant self-incompatibility. Ann Rev Plant Biol 2009, 60:21-42.

34. Hurst LD, Pal C, Lercher MJ: The evolutionary dynamics of eukaryotic gene order. Nat Rev Genet 2004, 5:299-310. 
35. Osbourn AE, Field B: Operons. Cell Mol Life Sci 2009, 66:3755-3775.

36. Golitz A, Sugano M, Hiradate S, Fujii Y: Microarray analysis of Arabidopsis plants in response to allelochemical L-DOPA. Planta 2011, 233:231-240.

37. Buckhout TJ, Yang TJ, Schmidt W: Early iron-deficiency-induced transcriptional changes in Arabidopsis roots as revealed by microarray analyses. BMC Genomics 2009, 10:147.

38. Weisman D, Alkio M, Colon-Carmona A: Transcriptional responses to polycyclic aromatic hydrocarbon-induced stress in Arabidopsis thaliana reveal the involvement of hormone and defense signaling pathways. BMC Plant Biol 2010, 10:59.

39. Shin DW, Ma J, Kim DH: The asp-rich region at the carboxyl terminus of calsequestrin binds to $\mathrm{Ca}^{2+}$ and interacts with triadin. FEBS Lett 2000, 486:178-182.

40. Ge LL, Tian HQ, Russell SD: Calcium function and distribution during fertilization in angiosperms. Am J Bot 2007, 94:1046-1060.

41. Jakobsen MK, Poulsen LR, Schulz A, Fleurat-Lessard P, Moller A, Husted S, Schiott M, Amtmann A, Palmgren MG: Pollen development and fertilization in Arabidopsis is dependent on the male gametogenesis impaired anthers gene encoding a type V P-type ATPase. Genes DeV 2005, 19:2757-2769.

42. Schiott M, Romanowsky SM, Baekgaard L, Jakobsen MK, Palmgren MG Harper JF: A plant plasma membrane $\mathrm{Ca}^{2+}$ pump is required for normal pollen tube growth and fertilization. Proc Natl Acad Sci USA 2004, 101:9502-9507.

43. Osbourn A: Gene clusters for secondary metabolic pathways: an emerging theme in plant biology. Plant Physiol 2010, 154:531-535.

44. Chu HY, Wegel E, Osbourn A: From hormones to secondary metabolism: the emergence of metabolic gene clusters in plants. Plant J 2011, 66:66-79.

45. Amoutzias G, Van de Peer Y: Together we stand: genes cluster to coordinate regulation. Dev Cell 2008, 14:640-642.

46. Agusti J, Merelo P, Cercos M, Tadeo FR, Talon M: Comparative transcriptional survey between laser-microdissected cells from laminar abscission zone and petiolar cortical tissue during ethylene-promoted abscission in citrus leaves. BMC Plant Biol 2009, 9:127.

47. Lohse $M$, Nunes-Nesi A, Krüger $P$, Nagel A, Hannemann J, Giorgi FM, Childs L, Osorio S, Walther D, Selbig J, Sreenivasulu N, Stitt M, Fernie AR, Usadel B: Robin: an intuitive wizard application for R-based expression microarray quality assessment and analysis. Plant Physiol 2010, 153:642-651.

48. Mesejo C, Martinez-Fuentes A, Reig C, Rivas F, Agusti M: The inhibitory effect of $\mathrm{CuSO} 4$ on pollen germination and pollen tube growth and its application for the production of seedless fruit. Plant Sci 2006, 170:37-43.

49. Tamura K, Peterson D, Peterson N, Stecher G, Nei M, Kumar S: MEGA5: molecular evolutionary genetics analysis using maximum likelihood, evolutionary distance, and maximum parsimony methods. Mol Biol Evol 2011, 28:2731-2739.

doi:10.1186/1471-2229-12-20

Cite this article as: Caruso et al: Comparative transcriptome analysis of stylar canal cells identifies novel candidate genes implicated in the selfincompatibility response of Citrus clementina. BMC Plant Biology 2012 $12: 20$.

\section{Submit your next manuscript to BioMed Central and take full advantage of:}

- Convenient online submission

- Thorough peer review

- No space constraints or color figure charges

- Immediate publication on acceptance

- Inclusion in PubMed, CAS, Scopus and Google Scholar

- Research which is freely available for redistribution 